\title{
Emotional and cognitive representation of COVID-19 among Polish adults during the peak of the second wave of the pandemic
}

\author{
Emocjonalna i poznawcza reprezentacja COVID-19 u dorosłych Polaków \\ w czasie szczytu drugiej fali pandemii
}

\author{
Institute of Psychology, Maria Curie-Skłodowska University, Lublin, Poland \\ Correspondence: Ewa Szepietowska, MD, PhD, Assoc. Prof., Department of Clinical Psychology and Neuropsychology, Maria Curie-Skłodowska University, Głęboka 45, 20-612 Lublin, Poland, \\ e-mail: ewa.szepietowska@poczta.umcs.lublin.pl, https://orcid.org/0000-0003-3383-0353; Sara Filipiak, PhD, Department of Clinical Psychology and Neuropsychology, Maria Curie-Skłodowska University, \\ Głęboka 45, 20-612 Lublin, Poland, e-mail: s.flipiak@poczta.umcs.lublin.pl, https://orcid.org/0000-0001-7818-7168
}

Instytut Psychologii, Uniwersytet im. Marii Curie-Skłodowskiej, Lublin, Polska

Adres do korespondencji: Ewa Szepietowska, Katedra Psychologii Klinizznej i Neuropsychologii, Uniwersytet im. Marii Curie-Skłodowskiej, ul. Głęboka 45, 20-612 Lublin,

e-mail: ewa.szepietowska@poczta.umcs.lublin.pl, https://orcid.org/0000-0003-3383-0353; Sara Filipiak, Katedra Psychologii Klinicznej i Neuropsychologii, Uniwersytet im. Marii Curie-Skłodowskiej, ul. Głęboka 45, 20-612 Lublin, e-mail: s.flipiak@poczta.umcs.lublin.pl, https://orcid.org/0000-0001-7818-7168

\begin{abstract}
Introduction: This paper presents the results of cognitive and emotional representation of COVID-19 in the sample of adult Poles during the peak of the second wave of the pandemic (November-December 2020). Aims: The study was designed to investigate the mental and emotional representation of COVID-19 in adult Poles. It was hypothesised that the representation would have a different structure depending on gender, age, education as well as personal experience of COVID-19 or other medical conditions. Methods: The survey was carried out in November and December 2020, and involved two hundred Polish adults aged 17 to 58 years $\left(M_{\text {age }}=32.59, S D=10.19\right)$. The subjects were surveyed via the Google Forms web survey platform. A link to the survey was sent to the participants on Facebook. Results: Three in four respondents were found to believe that COVID-19 indeed existed, and that a virus was the most important cause of the problem. According to nearly one in two respondents, the effects of the disease were exaggerated by the mass media. On average, the respondents tend to believe that the severity of the disease may be controlled by one's behaviour. The emotional representation of COVID-19 reflected predominantly negative emotions. The respondents were convinced that the disease led to significant consequences affecting the domains of personal life and work. Discussion: According to many participants, the effects of the disease are overestimated in media reports. The lack of knowledge about neurological and neuropsychological complications suggests that this aspect of the disease is insufficiently emphasised in the mass media during the second wave of the pandemic. Conclusions: Individual variables and experience of COVID-19 affect one's cognitive and emotional representation of the disease and one's beliefs concerning the mitigation of risks. This means that any future information related to COVID-19, and the promotion of knowledge concerning the possible mechanisms of disease development, must be conveyed in a way adjusted to gender and age as well as the level of education.
\end{abstract}

Keywords: cognitive and emotional representation of illness, COVID-19 pandemic, adult Poles

Streszczenie Wstęp: Artykuł prezentuje analizy dotyczące poznawczej i emocjonalnej reprezentacji COVID-19 u dorosłych Polaków w czasie szczytu drugiej fali pandemii (listopad-grudzień 2020 roku). Cel: Celem badania była analiza poznawczo-emocjonalnej reprezentacji COVID-19 u dorosłych Polaków. Na podstawie danych z piśmiennictwa założono, że reprezentacja ta ma odmienną strukturę zależnie od płci, wieku, poziomu wykształcenia oraz doświadczenia choroby COVID-19 lub innych czynników medycznych. Metoda: Badania przeprowadzono w listopadzie i grudniu 2020 roku. Uczestnikami byli dorośli Polacy w wieku 17-58 lat ( $\left.M_{\text {wiek }}=32,59 ; S D=10,19\right)$. W badaniach posłużono się formularzem Google. Link do ankiety online został rozesłany na portalu Facebook. Wyniki: Trzy czwarte badanych uważało, że COVID-19 istnieje, a za najistotniejszą przyczynę choroby uznało wirus. Prawie połowa ankietowanych sądziła, że skutki choroby są wyolbrzymiane przez media oraz że może ona przebiegać podobnie jak grypa. Przekonanie, iż poprzez swoje zachowanie można kontrolować przebieg COVID-19, miało przeciętne nasilenie, przeciętnie oceniana była także możliwość zapobiegania negatywnym skutkom choroby czy kontrolowania stanu zdrowia za pomocą leczenia. COVID-19 opisywany był jako choroba niezbyt łatwa do zrozumienia i niemająca większego sensu osobistego. W reprezentacji emocjonalnej przeważały emocje negatywne. Badani byli przekonani o znaczących skutkach choroby dla życia osobistego i zawodowego. Omówienie: Zdaniem wielu 
uczestników skutki COVID-19 są wyolbrzymiane przez media. Brak wiedzy o powikłaniach neurologicznych i neuropsychologicznych wskazuje, że ten aspekt choroby był zbyt słabo akcentowany w mediach w czasie szczytu drugiej fali pandemii. Wnioski: Zmienne indywidualne i doświadczenie COVID-19 mają znaczenie w kształtowaniu poznawczo-emocjonalnej reprezentacji choroby i przekonań na temat minimalizacji ryzyka zachorowania. Oznacza to, że w przyszłości informacje dotyczące COVID-19 i mechanizmów rozwoju choroby muszą być przekazywane w sposób dopasowany do płci, wieku czy wykształcenia odbiorców.

Słowa kluczowe: poznawcza i emocjonalna reprezentacja choroby, pandemia COVID-19, dorośli Polacy

\section{INTRODUCTION}

$\mathrm{T}$ The unprecedented situation encountered globally, i.e. the emergence of SARS-CoV-2 (causing COVID-19), has left its mark in all the spheres of life (Pacheco-Barrios et al., 2020). In Poland, the first case of the disease was identified on 4 March 2020 (Ministerstwo Zdrowia, 2020), and a few days later all schools were closed due to COVID-19 (Kancelaria Prezesa Rady Ministrów, 2020). On 20 March 2020, the state of epidemic was declared in Poland (Rozporządzenie Ministra Zdrowia z dnia 20 marca 2020 r.). The survey for the present study was carried out in late November/early December 2020, i.e. during the peak of the second wave of the pandemic, before the information about the availability of vaccines was published. On $11 \mathrm{De}-$ cember 2020, the statistics showed that by that time over 1.1 million Polish people had been infected and nearly 22,000 had died due to COVID-19 alone or with pre-existing conditions. It has been shown that there is an association between health-related behaviours or coping with a situation of illness, and the perception of the disease. The way the disease is seen is a combined effect of various factors, such as knowledge of the causes, and course of COVID-19 and other diseases, related personal experience, information received from other people, from patients or from the mass media, gender (Wang et al., 2020), as well socio-cultural factors, legal regulations, and religious beliefs (Boguszewski et al., 2020). Based on that, a mental representation of the disease is formed. It reflects the beliefs related to several components: identity (symptoms of illness), cause (precipitating factors), timeline (acute, chronic, or cyclical nature), consequences (impact of illness on social, psychological and physical functioning), control/cure (personal control over illness) and illness coherence (making sense of illness) (Bishop, 1991; Leventhal et al., 1998). The contents of the representation, which is often assessed by Illness Perception Questionnaire (IPQ-R) (Moss-Morris et al., 2002), affect one's evaluation of the risk, and behaviours related to healthcare or to a pandemic, like in this case.

A study showed that introduction of quarantine or lockdown contributed to the perception of COVID-19 as a dangerous disease. A period of isolation due quarantine was associated with increased mental health problems, e.g. more severe depression, and feeling discriminated (Litwin and Masiak,

\section{WPROWADZENIE}

$\mathrm{B}$ ezprecedensowa sytuacja o globalnym charakterze, jaką jest pandemia SARS-CoV-2 (COVID-19), dotknęła wszystkich sfer naszego życia (Pacheco-Barrios et al., 2020). W Polsce pierwszy przypadek choroby zidentyfikowano 4 marca 2020 roku (Ministerstwo Zdrowia, 2020), a kilka dni później z powodu COVID-19 zamknięto wszystkie szkoły (Kancelaria Prezesa Rady Ministrów, 2020). 20 marca 2020 roku w Polsce ogłoszono stan epidemii (Rozporządzenie Ministra Zdrowia z dnia 20 marca 2020 r.). Zaprezentowane tu badania przeprowadzono na przełomie listopada i grudnia 2020 roku - w czasie szczytu drugiej fali pandemii, przed pojawieniem się informacji o możliwości przyjęcia szczepienia. 11 grudnia 2020 roku statystyki wykazały, że ponad 1,1 miliona Polaków zostało dotąd zakażonych, a prawie 22 tysiące zmarło z powodu COVID-19 i/lub chorób współwystępujących.

Stwierdzono związek między zachowaniami zdrowotnymi czy radzeniem sobie z sytuacją choroby a percepcją COVID-19. Sposób postrzegania choroby jest wypadkową interakcji różnych czynników, do których należą: wiedza o przyczynach zachorowania, przebieg COVID-19 i innych chorób, osobiste doświadczenia, informacje uzyskane od osób chorych i z mediów, płeć (Wang et al., 2020), jak również czynniki społeczno-kulturowe, regulacje prawne i przekonania religijne (Boguszewski et al., 2020). Na tej podstawie tworzona jest mentalna reprezentacja choroby. Odzwierciedla ona przekonania na temat kilku komponentów: istoty (symptomów) choroby, jej przyczyn (przewidywanych czynników), przebiegu (ostrego, chronicznego lub cyklicznego) i konsekwencji (wpływu na funkcjonowanie społeczne, psychologiczne, fizyczne) oraz kontroli/leczenia (osobistej kontroli choroby) i koherencji (znaczenia choroby) (Bishop, 1991; Leventhal et al., 1998). Zawartość reprezentacji, często ocenianej za pomocą Illness Perception Questionnaire (IPQ-R) (Moss-Morris et al., 2002), dotyczy własnej oceny ryzyka i zachowań zdrowotnych lub - jak w omawianym przypadku - pandemii.

Badania wykazały, że wprowadzenie kwarantanny albo lockdownu było przyczyną oceniania COVID-19 jako choroby niebezpiecznej. Okres izolacji wynikający z kwarantanny wiązał się ze wzrostem problemów w zakresie zdrowia psychicznego, przykładowo z nasileniem depresji czy poczucia dyskryminacji (Litwin i Masiak, 2019), 
2020). The experience of a given community and awareness of the disease played an important role in the development of the COVID-19 representation. A study based on the IPQ-R, involving 118 patients and carried out in Hunan Province, China, in February 2020 (Liu et al., 2020), showed that the individuals whose relatives had also experienced the disease tended to perceive COVID-19 as a dangerous and incomprehensible disease, they lacked confidence in treatment, and presented poorer knowledge related to the problem, as compared to the patients whose families had not been infected. Perhaps this lack of awareness was the reason why the disease was spreading among relatives. On the other hand, a study carried out in April 2020 in Greece (Skapinakis et al., 2020), with an abridged version of the IPQ-R, showed high levels of personal control and self-efficacy with regard to COVID-19, whereas less than $30 \%$ of the respondents viewed the illness as potentially severe. Gender also determines the mental and emotional representation of COVID-19. Studies conducted in China (Wang et al., 2020; Zhang et al., 2020), Turkey (Yıldırım and Güler, 2020), Greece (Skapinakis et al., 2020), and Germany (Gerhold, 2020) showed a predominance of anxiety and hyper-sensitivity in women. Reports from Polish studies conducted between the first wave of the pandemic and December 2020 (Uniwersytet Warszawski: Raporty z badań ekspertów) showed, among other findings, a decrease in negative emotions related to the pandemic over consecutive measurements, an association between generalised anxiety and depression intensity and such experiences as self-isolation or quarantine, as well as declining popularity of the so-called conspiracy theories. However, other reports related to the perception of the causes of the disease, dating from April 2020, showed that $44 \%$ of survey participants in Poland believed that SARS-CoV-2 was a product of a laboratory in Wuhan, $27 \%$ agreed that it was an effect of the natural evolution of the SARS virus, $3 \%$ of the respondents thought that the coronavirus was fake news, and 3\% believed that it was a product of $5 \mathrm{G}$ technology (BCMM, 2020).

In view of the significant dynamics of COVID-19 related infections and deaths in Poland during November-December 2020, and given a lack of current reports concerning the emotional and cognitive representation of COVID-19 in adult Poles, this study aimed to describe the representation of COVID-19, including people's beliefs related to its causes and ways to mitigate the risk of infection. Based on the existing evidence, it was hypothesised that the representation would have a different structure depending on gender, age, education, and personal experience of COVID-19 or other medical conditions. The representation was also assessed for its impact on people's behaviours towards COVID-19 vaccines.

\section{METHODS}

The research was carried out within the framework of a broader project related to the impact of the COVID-19 pandemic on various domains of Polish adults' life. The present study was conducted in accordance with the Declaration of Helsinki, and i z niekorzystnymi zmianami w stylu życia (Górnicka et al., 2020). W tworzeniu reprezentacji COVID-19 istotną rolę odgrywały doświadczenia danej społeczności i wiedza o chorobie. W badaniach z wykorzystaniem IPQ-R przeprowadzonych wśród 118 chorych z prowincji Hunan w lutym 2020 roku (Liu et al., 2020) stwierdzono, że pacjenci, których bliscy również chorowali, postrzegali COVID-19 jako chorobę groźną i niezrozumiałą, nie mieli zaufania do leczenia oraz wiedzieli o chorobie mniej niż pacjenci, których rodziny nie były zakażone; niewykluczone, iż właśnie brak wiedzy był powodem rozprzestrzeniania się choroby wśród bliskich. Z kolei badania greckie z kwietnia 2020 roku (Skapinakis et al., 2020), w których użyto skróconej wersji IPQ-R, wykazały wysoki poziom poczucia osobistej kontroli i samoskuteczności odnośnie do COVID-19, a mniej niż 30\% respondentów postrzegało chorobę jako potencjalnie ciężką. Poznawczo-emocjonalną reprezentację COVID-19 determinuje też płeć. Badania wykonane w Chinach (Wang et al., 2020; Zhang et al., 2020), Turcji (Yıldırım i Güler, 2020), Grecji (Skapinakis et al., 2020) i Niemczech (Gerhold, 2020) wskazały na przewagę lęku i nadwrażliwości $\mathrm{u}$ kobiet. $\mathrm{W}$ raportach $\mathrm{z}$ badań polskich prowadzonych od pierwszej fali pandemii do grudnia 2020 roku (Uniwersytet Warszawski: Raporty z badań ekspertów) zwrócono uwagę na spadek negatywnych emocji towarzyszących pandemii w kolejnych pomiarach, związek nasilenia lęku uogólnionego i depresji z pobytem w izolacji lub na kwarantannie, a także spadek popularności teorii spiskowych. Jednak według innych doniesień na temat percepcji przyczyn choroby, z kwietnia 2020 roku, zdaniem 44\% ankietowanych Polaków SARS-CoV-2 został stworzony w laboratorium w Wuhan, podczas gdy $27 \%$ respondentów zgadzało się ze stwierdzeniem, że to efekt naturalnej ewolucji wirusa SARS, 3\% - że koronawirus jest plotką (fake news), również $3 \%$ - że to produkt technologii 5G (BCMM, 2020).

Wobec znaczącej dynamiki pandemii, dużej liczby zakażeń i śmierci w Polsce w listopadzie i grudniu 2020 roku oraz braku aktualnych doniesień poświęconych emocjonalnej i poznawczej reprezentacji COVID-19 u dorosłych Polaków podjęto badania mające na celu opis reprezentacji COVID-19, obejmującej przekonania ankietowanych na temat przyczyn choroby i sposobów zapobiegania infekcji. Na podstawie istniejących dowodów założono, że reprezentacja ta ma odmienną strukturę zależnie od płci, wieku, edukacji i osobistych doświadczeń związanych z COVID-19 lub innych czynników medycznych. Reprezentację choroby można także oceniać pod kątem jej wpływu na zachowania ludzi wobec szczepionek przeciw COVID-19.

\section{METODY}

Prezentowane badania zostały zrealizowane $\mathrm{w}$ ramach szerszego projektu, który dotyczył wpływu pandemii COVID-19 na różne sfery życia dorosłych Polaków. Badania przeprowadzono zgodnie z Deklaracja helsińska, a protokół zaakceptowała Komisja ds. Etyki Badań przy 
the protocol was approved by the Ethics Committee for Scientific Research at Maria Curie-Skłodowska University (No. 34/2020). The invitation to voluntary participation in the study was addressed to Polish adults. It was conducted using the Google Forms web survey platform. A link to the survey was shared through Facebook. As a result, we were able to conduct a nationwide survey during the rapidly changing pandemic situation when face-to-face surveys became impossible due to lockdown. The respondents were informed about the purpose of the study and about the option to withdraw at any time. After they expressed their consent, the respondents received an online survey with an instruction for completing the questionnaire. The survey contained questions related to general opinions regarding COVID-19, as well as demographic and personal data (such as gender, age, education, existing chronic diseases, history of COVID-19 infection, information about the disease acquired from medical professionals) (Tab. 1), the IPQ-R, and a list of 16 behaviours recognised as helpful in mitigating the risk of COVID-19. No information was collected to enable identification of the participants. Incomplete questionnaires were disregarded, and ultimately the analyses included two hundred individuals, including 151 (75.5\%) females and 49 $(24.5 \%)$ males, ranging in age from 17 to 58 years $(M=32.59$, standard deviation, $S D=10.19$ ). The group comprised predominantly representatives of early adulthood and the initial stage of middle adulthood, which generally reflected the age structure of adult citizens of Poland in 2019 and 2020 (Ambroch, 2020). The online method of collecting data may be the reason why the populations of senior citizens and individuals with elementary education were underrepresented. Tab. 1 shows other characteristics of the respondents.

\section{Cognitive and emotional representation of COVID-19}

The assessment of the cognitive and emotional representation of COVID-19 was carried out using the Revised Illness Perception Questionnaire (IPQ-R) (Moss-Morris et al., 2002). The IPQ-R comprises the following subscales: Illness Identity - symptoms associated by respondents with COVID-19; Timeline Acute/Chronic (6 items), Timeline Cyclical (4), Consequences (6), Personal Control (6), Treatment Control (5), Illness Coherence (5), Emotional Representations (6), and Causal Representations (16), namely: psychological attributions, risk factors, immunity, and accidental or chance. Validation studies showed good psychometric properties of the original scale (Moss-Morris et al., 2002), and of its Polish version (Pasternak et al., 2021). The IPQ-R was initially validated in patients with chronic diseases, and currently it is used in COVID-19 perception studies. The original contents of the IPQ- $\mathrm{R}$ were modified with references to COVID-19, added in the instruction. The respondents were requested to assess each item on a 5-point scale. For example, in the Consequences subscale, the items were as follows: a) The condition of a patients with COVID-19 may be se-

\begin{tabular}{|c|c|}
\hline $\begin{array}{c}\text { Variables } \\
\text { Zmienne }\end{array}$ & $n(\%)$ \\
\hline $\begin{array}{l}\text { Level of education: } \\
\text { Poziom edukacji: } \\
\text { - lower level (elementary, vocational, secondary and undergraduate) } \\
\text { niżzy (wykstałcenie podstawowe, zawodowe, średniei licencjackie) } \\
\text { - higher level (graduate and post-graduate) } \\
\text { wyższy (wyksztatcenie magisterskie i podyplomowe) }\end{array}$ & $\begin{array}{l}99(49.5 \%) \\
101(50.5 \%)\end{array}$ \\
\hline $\begin{array}{l}\text { Activity: } \\
\text { Aktywnośc: } \\
\text { - working } \\
\text { pracujący } \\
\text { - students } \\
\text { studenci } \\
\text { - retired } \\
\text { renciści/emeryci }\end{array}$ & $\begin{array}{l}141(70.5 \%) \\
49(24.5 \%)\end{array}$ \\
\hline $\begin{array}{l}\text { History of chronic medical conditions: } \\
\text { Historia chorób przewlekłych: } \\
\text { - yes } \\
\text { tak } \\
\text { - no } \\
\text { nie }\end{array}$ & $\begin{array}{c}47(23.6 \%) \\
153(76.5 \%)\end{array}$ \\
\hline $\begin{array}{l}\text { COVID-19 (confirmed with tests and medical diagnosis): } \\
\text { cOVID-19 (choroba potwierdzona testami i diagnozą medyczna): } \\
\text { - yes } \\
\text { tak } \\
\text { - no } \\
\text { nie }\end{array}$ & $\begin{array}{c}12(6 \%) \\
188(94 \%)\end{array}$ \\
\hline $\begin{array}{l}\text { Quarantine (due to COVID-19 or because of a contact with } \\
\text { an infected person): } \\
\text { Kwarantanna (z powodu zakażenia COVID-19 lub kontaktu } \\
\text { z osoba chora): } \\
\text { - yes } \\
\text { tak } \\
\text { - no } \\
\text { nie }\end{array}$ & $160(80 \%)$ \\
\hline $\begin{array}{l}\text { Contact (in person or via phone) with someone who had COVID-19: } \\
\text { Kontakt (osobisty lub telefoniczny) z kimś chorym na COVID-19: } \\
\text { - yes } \\
\text { tak } \\
\text { - no } \\
\text { nie }\end{array}$ & $\begin{array}{l}121(60.5 \%) \\
79(39.5 \%)\end{array}$ \\
\hline $\begin{array}{l}\text { Contact with people taking care of patients with COVID-19: } \\
\text { Kontakt z osobami opiekujacymi się chorymi z COVID-19: } \\
\text { - yes } \\
\text { tak } \\
\text { - no } \\
\text { nie }\end{array}$ & $\begin{array}{l}93(46.5 \%) \\
107(53.5 \%)\end{array}$ \\
\hline $\begin{array}{l}\text { COVID-19 is a really existing and dangerous disease: } \\
\text { COVID-19 istnieje rzeczywiście i jest niebezpieczna chorobą: } \\
\text { • yes } \\
\text { tak } \\
\text { - I'm not sure } \\
\text { niejestem pewien } \\
\text { - no } \\
\text { nie }\end{array}$ & $\begin{array}{l}141(70.5 \%) \\
51(25.5 \%)\end{array}$ \\
\hline $\begin{array}{l}\text { Politicians and mass media overestimate the effects of COVID-19: } \\
\text { Politycy imedia wyolbrzymiajq efekty COVID-19: } \\
\text { - yes } \\
\text { tak } \\
\text { - I'm not sure } \\
\text { nie jestem pewien } \\
\text { - no } \\
\text { nie }\end{array}$ & $\begin{array}{l}96(48 \%) \\
70(35 \%)\end{array}$ \\
\hline $\begin{array}{l}\text { COVID is as dangerous as influenza: } \\
\text { COVID-19 jest tak niebezpieczny jak grypa: } \\
\text { - yes } \\
\text { tak } \\
\text { - I'm not sure } \\
\text { nie jestem pewien } \\
\text { - COVID was more dangerous than influenza } \\
\text { cOVID-19 jest bardziejgroźny niż grypa } \\
\end{array}$ & 119 (59.5\%) \\
\hline
\end{tabular}

Tab. 1. Characteristics of the respondents

Tab. 1. Charakterystyka uczestników 
c) COVID-19 has a significant impact on life; d) COVID-19 seriously influences on the way how a sick person is perceived by the others; e) COVID-19 has serious financial consequences; f) COVID-19 creates serious problems for relatives. In the subscales of the IPQ-R (Timeline Acute/Chronic; Timeline Cyclical; Consequences; Personal Control; Treatment Control; Illness Coherence and Emotional Representations) the responses were scored according to a Likert scale, in the following manner: 1 - "strongly disagree," 2 "disagree," 3 - "hard to say," 4 - "agree," 5 - "strongly agree." In the Illness Identity subscale, the respondents were asked to determine to what degree a specific symptom is typical for COVID-19 (on a 5-point Likert scale, where 1 meant "strongly disagree," and 5 - "strongly agree"). A list of 21 symptoms was prepared based on epidemiologic data [Mayo Clinic: Coronavirus disease 2019 (COVID-19). Symptoms and causes; World Health Organization: Coronavirus disease (COVID-19). Symptoms]. High scores on the identity, timeline, consequences and cyclical dimensions represent strongly held beliefs about the importance and number of symptoms attributed to COVID, chronic course of the condition, negative consequences of the illness, and the cyclical nature of the condition. High scores in personal control, treatment control and coherence dimensions represent positive beliefs about the controllability of COVID and personal understanding of the condition.

Opinions related to the possible causes of COVID-19 (16 items) were also assessed on a Likert scale, from 1 "strongly disagree," to 5 - "strongly agree." The list of causes was compiled based on the data from research publications [Mayo Clinic: Coronavirus disease 2019 (COVID-19). Symptoms and causes].

\section{Behaviours minimising a risk of infection}

A list of 16 behaviours recognised as helpful in mitigating a risk of COVID-19, was developed [Cirrincione et al., 2020; Mayo Clinic: Coronavirus disease 2019 (COVID-19). Symptoms and causes], and the respondents were asked to assess their importance for reducing the risk of infection. Again, a Likert scale was applied (1 - "strongly disagree," 5 - "strongly agree").

All statistical analyses were performed using SPSS 26. Nonparametric tests (Mann-Whitney $U$ test for two groups, Spearman's rank correlation coefficient) as well as a categorical regression (CATREG) for quantitative and qualitative data were applied to capture the determinants of COVID-19 representation.

\section{RESULTS}

\section{COVID-19 identity}

According to the Polish respondents, the main symptoms of COVID-19 include the loss of smell, taste, and physical strength, fever, shortness of breath, cough, fatigue,
Uniwersytecie im. Marii Curie-Skłodowskiej (nr 34/2020). Do dobrowolnego uczestnictwa zaproszono osoby dorosłe. Badania zrealizowano za pomocą ankiety na platformie Google Forms, link do ankiety przekazano za pośrednictwem Facebooka. W rezultacie udało się przeprowadzić ogólnopolskie badania w okresie szybko zmieniającej się sytuacji pandemicznej, gdy badania bezpośrednie stały się niemożliwe $\mathrm{z}$ powodu lockdownu. Respondentów informowano o możliwości udziału w badaniach i wycofania się z nich w dowolnym momencie. Po wyrażeniu zgody uczestnicy otrzymywali drogą internetową ankietę wraz z instrukcją wypełniania kwestionariuszy.

Kwestionariusz zawierał pytania dotyczące ogólnych poglądów na temat COVID-19, danych demograficznych i indywidualnych (m.in. płci, wieku, wykształcenia, obecności chorób przewlekłych, przebycia zakażenia COVID-19, informacji o chorobie pozyskanych od personelu medycznego) (tab. 1), IPQ-R oraz listę 16 zachowań określonych jako pomocne w minimalizacji ryzyka zachorowania na COVID-19. Nie zbierano danych, które pozwoliłyby na identyfikację uczestników. Niekompletne kwestionariusze były pomijane. Ostatecznie analizy uwzględniły 200 respondentów w wieku 17-58 lat $(M=32,59$; odchylenie standardowe, standard deviation, $S D=10,19): 151(75,5 \%)$ kobiet i 49 (24,5\%) mężczyzn. Grupa składała się głównie z osób na etapie wczesnej dorosłości i początkowym etapie średniej dorosłości, co generalnie odzwierciedla strukturę wieku w populacji dorosłych Polaków w 2019 i 2020 roku (Ambroch, 2020). Zbieranie danych online mogło być powodem niskiej liczebności uczestników w wieku senioralnym i z wykształceniem podstawowym. Charakterystykę respondentów przedstawia tab. 1 .

\section{Poznawcza i emocjonalna reprezentacja COVID-19}

Poznawczą i emocjonalną reprezentację COVID-19 oceniono z wykorzystaniem Revised Illness Perception Questionnaire (IPQ-R) (Moss-Morris et al., 2002). IPQ-R zawiera następujące podskale: Istota choroby (symptomy wiązane przez respondentów z COVID-19), Przebieg ostry/chroniczny (6 itemów), Cykliczność przebiegu (4), Konsekwencje (6), Kontrola osobista (6), Kontrola leczenia (5), Koherencja choroby (5), Reprezentacja emocjonalna (6) i Reprezentacja przyczyn (16); ostatnia podskala odnosi się głównie do atrybucji psychologicznych, czynników ryzyka, odporności oraz przypadku/pecha. Badania walidacyjne wykazały dobre właściwości psychometryczne oryginalnej skali (Moss-Morris et al., 2002), podobne wyniki uzyskano w badaniach polskich (Pasternak et al., 2021). IPQ-R był początkowo walidowany w grupach pacjentów z chorobami przewlekłymi, obecnie zaś jest używany w badaniach nad percepcją COVID-19. Oryginalna instrukcja IPQ-R została zmodyfikowana przez dodanie odniesienia do COVID-19. Respondenci oceniali każde stwierdzenie na 5-punktowej skali. Przykładowo w podskali Konsekwencje znalazły się następujące stwierdzenia: a) Stan chorego na COVID-19 może być 


\begin{tabular}{|c|c|}
\hline $\begin{array}{l}\text { COVID symptoms } \\
\text { Objawy COVID-19 }\end{array}$ & $M(S D)$ \\
\hline $\begin{array}{l}\text { Muscle pain } \\
\text { Bóle mięśni }\end{array}$ & $4.24(0.99)$ \\
\hline $\begin{array}{l}\text { Stomach problems (nausea, diarrhoea) } \\
\text { Problemy żoładkowe (nudności, biegunka) }\end{array}$ & $3.34(1.13)$ \\
\hline $\begin{array}{c}\text { Shortness of breath } \\
\text { Duszności }\end{array}$ & $4.61(0.68)$ \\
\hline $\begin{array}{l}\text { Body weight change } \\
\text { Zmiana wagi ciała }\end{array}$ & $2.53(1.08)$ \\
\hline $\begin{array}{l}\text { Fatigue } \\
\text { Męczliwość }\end{array}$ & $4.44(0.80)$ \\
\hline $\begin{array}{l}\text { Joint stiffness } \\
\text { Sztywnośćstawów }\end{array}$ & $3.11(1.14)$ \\
\hline $\begin{array}{c}\text { Eye irritation } \\
\text { Swędzenie oczu }\end{array}$ & $2.60(1.20)$ \\
\hline $\begin{array}{l}\text { Sleep disturbances } \\
\text { Zaburzenia snu }\end{array}$ & $2.71(1.16)$ \\
\hline $\begin{array}{c}\text { Dizziness } \\
\text { Zawroty głowy }\end{array}$ & $3.29(1.15)$ \\
\hline $\begin{array}{l}\text { Loss of physical strength } \\
\text { Utrata sity fizycznej }\end{array}$ & $4.36(0.81)$ \\
\hline $\begin{array}{c}\text { Wheezing } \\
\text { Świszczący oddech }\end{array}$ & $3.96(1.09)$ \\
\hline $\begin{array}{l}\text { Cough } \\
\text { Kaszel } \\
\end{array}$ & $4.52(0.83)$ \\
\hline $\begin{array}{l}\text { Fever } \\
\text { Gorqqzka }\end{array}$ & $4.58(0.84)$ \\
\hline $\begin{array}{c}\text { Rash } \\
\text { Wysypka }\end{array}$ & $2.51(1.10)$ \\
\hline $\begin{array}{c}\text { Speech impairments } \\
\text { Zaburzenia mowy }\end{array}$ & $2.22(1.07)$ \\
\hline $\begin{array}{l}\text { Paresis of the upper and/or lower limbs } \\
\text { Niedowłady kończyn górnych i/lub dolnych }\end{array}$ & $2.17(1.01)$ \\
\hline $\begin{array}{c}\text { Loss of smell and taste } \\
\text { Utrata węchu i smaku }\end{array}$ & $4.57(0.81)$ \\
\hline $\begin{array}{l}\text { Sore throat } \\
\text { Ból gardła }\end{array}$ & $3.82(1.08)$ \\
\hline $\begin{array}{c}\text { Runny nose } \\
\text { Katar }\end{array}$ & $3.50(1.15)$ \\
\hline $\begin{array}{l}\text { Memory or thinking disorders } \\
\text { Zaburzenia pamięci i myślenia }\end{array}$ & $2.41(1.15)$ \\
\hline $\begin{array}{l}\text { Symptoms in the oral cavity } \\
\text { Objawy w obrębie jamy ustnej }\end{array}$ & $2.41(1.03)$ \\
\hline
\end{tabular}

Tab. 2. Representation of COVID-19 identity (means and standard deviations)

Tab. 2. Reprezentacja istoty COVID-19 (średnie i odchylenia standardowe)

muscle pain, and to a lesser degree - stomach problems, runny nose, and sore throat; the least typical are neurological symptoms and neuropsychological problems (Tab. 2). Males (m) were more likely than females (f) to recognise the following symptoms as important for the clinical picture of COVID-19: body weight change $\left(M_{\mathrm{m}}=2.9, S D=1.20\right.$; $\left.M_{\mathrm{f}}=2.4, S D=1.03, p<0.05\right)$, sleep disturbances $\left(M_{\mathrm{m}}=2.98\right.$, $\left.S D=1.14 ; M_{\mathrm{f}}=2.62, S D=1.09, p<0.05\right)$, dizziness $\left(M_{\mathrm{m}}=3.37\right.$, $\left.S D=1.0 ; M_{\mathrm{f}}=3.20, S D=1.19, p=0.05\right)$ as well as memory and thinking disorders $\left(M_{\mathrm{m}}=2.71, S D=1.11 ; M_{\mathrm{f}}=2.31, S D=1.16\right.$, poważny; b) COVID-19 ma poważne konsekwencje dla życia; c) COVID-19 ma istotny wpływ na życie; d) COVID-19 poważnie wpływa na to, jak chory jest spostrzegany przez innych; e) COVID-19 ma poważne konsekwencje finansowe; f) COVID-19 tworzy poważne kłopoty dla bliskich chorego. W podskalach IPQ-R (Przebieg ostry/chroniczny, Cykliczność przebiegu, Konsekwencje, Kontrola osobista, Kontrola leczenia, Koherencja choroby, Reprezentacja emocjonalna) odpowiedzi były punktowane zgodnie ze skalą Likerta: 1 - zdecydowanie nie, 2 - raczej nie, 3 - trudno powiedzieć, 4 - raczej tak, 5 - zdecydowanie tak. W podskali Istota choroby COVID-19 respondenci mieli określić, w jakim stopniu każdy symptom jest typowy dla COVID-19 (również na 5-punktowej skali Likerta, gdzie 1 pkt oznaczał „zdecydowanie nie”, a 5 - „zdecydowanie tak”). Listę 21 symptomów przygotowano na podstawie danych epidemicznych [Mayo Clinic: Coronavirus disease 2019 (COVID-19). Symptoms and causes; World Health Organization: Coronavirus disease (COVID-19). Symptoms].

Wysokie wyniki w podskalach Istota choroby, Przebieg ostry/ chroniczny, Konsekwencje i Cykliczność przebiegu wskazują na silne przekonanie o dużej wadze i liczbie symptomów przypisywanych COVID-19, przewlekłym przebiegu choroby, jej negatywnych konsekwencjach i cyklicznej naturze. Wysokie wyniki w Kontroli osobistej, Kontroli leczenia i Koherencji choroby odpowiadają pozytywnym przekonaniom o możliwości kontroli COVID-19 i osobistemu rozumieniu choroby. Opinie dotyczące możliwych przyczyn COVID-19 (16 itemów) także były oceniane na skali Likerta, od 1 pkt - „zdecydowanie nie” do 5 - „zdecydowanie tak”. Lista przyczyn powstała na podstawie danych z publikacji naukowych [Mayo Clinic: Coronavirus disease 2019 (COVID-19). Symptoms and causes].

\section{Zachowania minimalizujące ryzyko zakażenia}

W kwestionariuszu zawarto listę 16 zachowań określonych jako istotne dla minimalizacji ryzyka zakażenia SARS-CoV-2 [Cirrincione et al., 2020; Mayo Clinic: Coronavirus disease 2019 (COVID-19). Symptoms and causes], a respondentów poproszono o ocenę znaczenia każdego z nich. Ponownie wykorzystano skalę Likerta (1 - „zdecydowanie nie”, 5 - „zdecydowanie tak”).

Wszystkie analizy statystyczne wykonano przy użyciu SPSS 26. Zastosowane zostały testy nieparametryczne (test U Manna-Whitneya dla dwóch grup, współczynnik korelacji rangowej Spearmana) oraz regresja kategorialna (CATREG) dla danych ilościowych i jakościowych w celu wskazania determinantów reprezentacji COVID-19.

\section{WYNIKI}

\section{Istota COVID-19}

Według respondentów główne symptomy COVID-19 to: zaburzenia węchu, smaku, siły fizycznej, gorączka, duszności, 


\begin{tabular}{|c|c|}
\hline $\begin{array}{c}\text { Subscales IPQ-R } \\
\text { Podskale IPQ- } R\end{array}$ & $\mathbf{M}($ SD) \\
\hline $\begin{array}{c}\text { Timeline Acute/Chronic } \\
\text { Przebieg ostry/chroniczny }\end{array}$ & 19.52 (4.42) \\
\hline $\begin{array}{c}\text { Timeline Cyclical } \\
\text { Cykliczność przebiegu }\end{array}$ & $14.59(3.09)$ \\
\hline $\begin{array}{c}\text { Consequences } \\
\text { Konsekwencje }\end{array}$ & $22.46(4.65)$ \\
\hline $\begin{array}{c}\text { Personal Control } \\
\text { Kontrola osobista }\end{array}$ & $18.77(4.9)$ \\
\hline $\begin{array}{c}\text { Treatment Control } \\
\text { Kontrola leczenia }\end{array}$ & $13.45(3.77)$ \\
\hline $\begin{array}{c}\text { Illness Coherence } \\
\text { Koherencja choroby }\end{array}$ & $9.85(3.45)$ \\
\hline $\begin{array}{c}\text { Emotional Representations } \\
\text { Reprezentacja emocjonalna }\end{array}$ & $23.46(6.47)$ \\
\hline
\end{tabular}

Tab. 3. Raw scores in IPQ-R $(\mathrm{n}=200)$ (means and standard deviations)

Tab. 3. Wyniki surowe $w$ IPQ-R $(\mathrm{n}=200)$ (średnie $i$ odchylenia standardowe)

of COVID-19 (nC), those who had been infected (C) more frequently pointed to muscle pain $\left(M_{\mathrm{C}}=4.75, S D=0.62\right.$; $\left.M_{\mathrm{nC}}=4.20, S D=1.00, p<0.05\right)$. The respondents who had had contact with a patient with COVID-19 were more likely to select sore throat as one of the significant symptoms compared to those who had had no such contact $(M=3.94, S D=1.02$; $M=3.63, S D=1.14, p<0.05)$. The survey participants who had talked with caregivers/doctors were more likely than the others to recognise memory disorders as an important feature of the clinical picture of COVID-19 $(M=2.57, S D=1.24$; kaszel, zmęczenie, bóle mięśni, a w mniejszym stopniu dolegliwości żołądkowe, katar i ból gardła; za najmniej typowe badani uznali objawy neurologiczne i problemy neuropsychologiczne (tab. 2).

Mężczyźni (m) w porównaniu z kobietami (f) byli bardziej skłonni określać jako istotne w obrazie klinicznym COVID-19 następujące symptomy: zmiany wagi ciała $\left(M_{\mathrm{m}}=2,9, S D=1,20 ; M_{\mathrm{f}}=2,4, S D=1,03, p<0,05\right)$, zakłócenia snu $\left(M_{\mathrm{m}}=2,98, S D=1,14 ; M_{\mathrm{f}}=2,62, S D=1,09\right.$, $p<0,05)$, zawroty głowy $\left(M_{\mathrm{m}}=3,37, S D=1,0 ; M_{\mathrm{f}}=3,20\right.$, $S D=1,19, p=0,05)$, zaburzenia pamięci i myślenia $\left(M_{\mathrm{m}}=2,71, S D=1,11 ; M_{\mathrm{f}}=2,31, S D=1,16, p<0,05\right)$. $\mathrm{W}$ porównaniu z respondentami, którzy nie deklarowali przechorowania COVID-19 (nC), ci, którzy deklarowali, że przeszli zakażenie (C), częściej wskazywali na bóle mięśniowe $\left(M_{\mathrm{C}}=4,75, S D=0,62 ; M_{\mathrm{nC}}=4,20, S D=1,00\right.$, $p<0,05)$. Badani, którzy mieli kontakt $\mathrm{z}$ osobą chorą na COVID-19, częściej zaliczali ból gardła do istotnych symptomów niż ci, którzy nie mieli takiego kontaktu (odpowiednio $M=3,94, S D=1,02 ; M=3,63, S D=1,14, p<0,05)$. Uczestnicy, którzy rozmawiali z opiekunami/lekarzami, byli bardziej skłonni niż pozostali badani wskazywać na zaburzenia pamięci jako istotną cechę obrazu klinicznego COVID-19 $(M=2,57, S D=1,24 ; M=2,26, S D=1,06$, $p=0,05)$. Respondenci z niższym poziomem wykształcenia (LL) w porównaniu $z$ osobami $z$ wyższym poziomem edukacji (HL) za mniej typowe dla COVID-19 uznali duszności $\left(M_{\mathrm{LL}}=4,52, S D=0,76 ; M_{\mathrm{HL}}=4,71, S D=0,57\right.$, $p=0,05)$ oraz utratę węchu i smaku $\left(M_{\mathrm{LL}}=4,43, S D=0,90\right.$; $\left.M_{\mathrm{HL}}=4,71, S D=0,015, p<0,05\right)$.

\section{COVID-19 representation \\ Reprezentacja COVID-19}

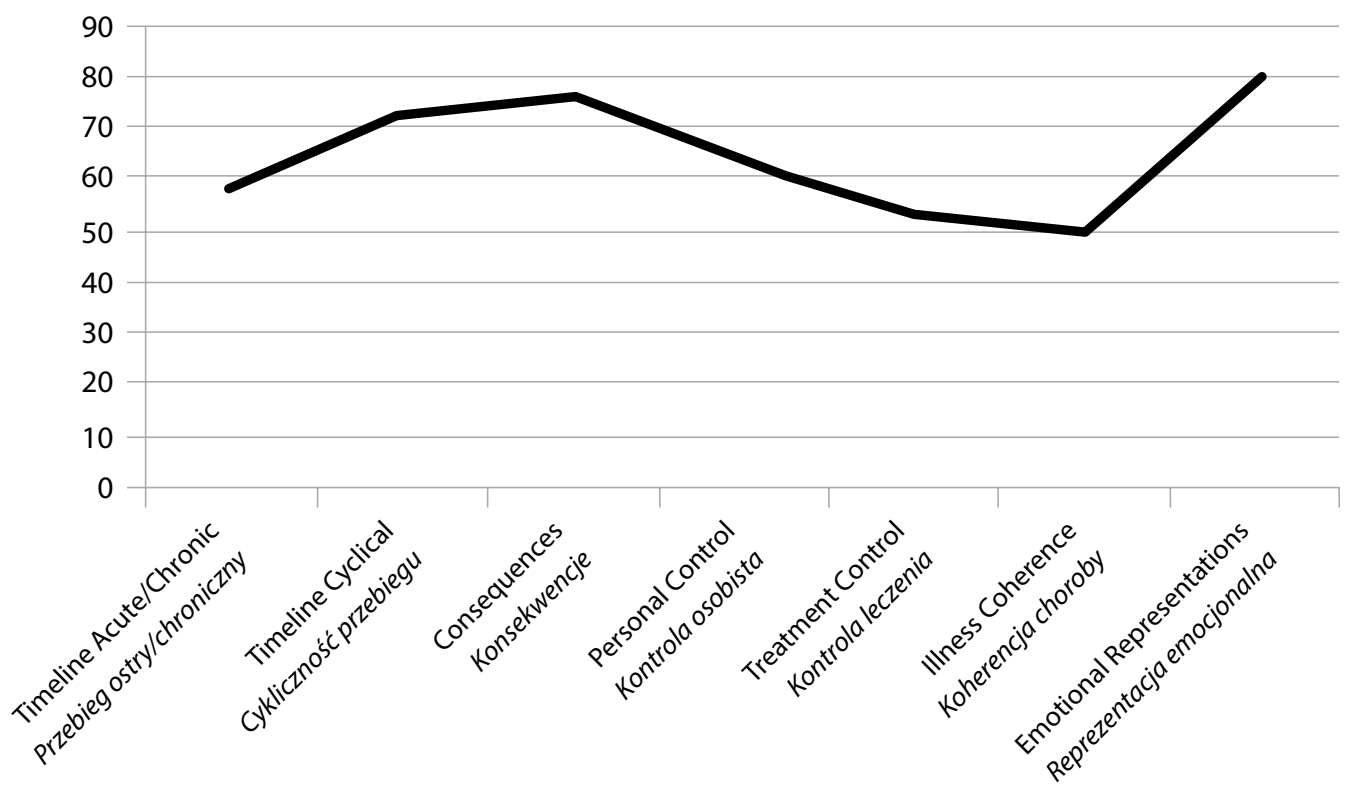

Fig. 1. Cognitive and emotional representation of COVID-19 (results of the IPQ-R subscales presented as percent values)

Ryc. 1. Poznawcza i emocjonalna reprezentacja COVID-19 (wyniki w podskalach IPQ-R prezentowane na skali procentowej) 
$M=2.26, S D=1.06, p=0.05)$. The respondents with lower education (LL), compared to those with higher education (HL) recognised the following symptoms of COVID-19 to be less typical: shortness of breath $\left(M_{\mathrm{LL}}=4.52, S D=0.76 ; M_{\mathrm{HL}}=4.71\right.$, $S D=0.57, p=0.05)$ and loss of smell and taste $\left(M_{\mathrm{LL}}=4.43\right.$, $\left.S D=0.90 ; M_{\mathrm{HL}}=4.71, S D=0.015, p<0.05\right)$.

\section{Timeline Acute/Chronic, Timeline Cyclical, Consequences, Personal Control, Treatment Control, IIIness Coherence and Emotional Representations of COVID-19}

Since the subscales comprise different numbers of items, the raw results (Tab. 3) were expressed in percent values. As a result, it was possible to determine a profile of cognitive and emotional representation of COVID-19 (Fig. 1). According to all the respondents, COVID-19 pandemic elicits in them negative emotions (Emotional Representations), and is perceived as a disease significantly affecting one's personal life (Consequences). The disease tends to be seen more as a long-term problem than a severe short-term condition (Timeline Acute/Chronic), and it is associated with frequent aggravation and then withdrawal of the symptoms (Timeline Cyclical). The respondents displayed a moderate belief that the course of the disease (improvement or deterioration) can be affected by one's behaviour (Personal Control). They presented a slightly lower belief that treatment might effectively improve one's condition or prevent negative outcomes (Treatment Control). COVID-19 was perceived as a mysterious disease, which was not easy to comprehend (Illness Coherence). Women tended to report stronger negative emotions in relation to COVID-19, compared to men $(M=23.96, S D=6.21$; $M=21.93, S D=7.09, p=0.05)$. The respondents who had talked with caregivers/doctors about COVID-19 were more likely than the others to recognise the chronic nature of the disease $(M=20.50, S D=4.44 ; M=18.61, S D=4.23, p<0.01)$ and its serious consequences $(M=23.29, S D=4.37 ; M=21.77$, $S D=4.79, p<0.01)$. With age, there was a growing conviction that the disease might lead to negative consequences $(\rho=0.18$, $p<0.05)$. The individuals with chronic diseases $(\mathrm{ChD})$ presented different opinions than those reporting no such conditions (nChD): the former believed COVID-19 was a long-lasting disease $\left(M_{\mathrm{ChD}}=20.76, S D=3.77 ; M_{\mathrm{nChD}}=19.15, S D=4.55\right.$, $p<0.05)$ rather than a short-term condition. The individuals with higher education (HL) presented a significantly higher rating of negative consequences of the disease $\left(M_{\mathrm{LL}}=21.30\right.$, $\left.S D=4.80 ; M_{\mathrm{HL}}=23.55, S D=4.26, p \leq 0.001\right)$, and were more likely to perceive COVID-19 as a condition of chronic rather than acute nature $\left(M_{\mathrm{HL}}=14.90, S D=3.03 ; M_{\mathrm{LL}}=14.26\right.$, $S D=3.06, p=0.05)$.

\section{Causal representation}

The most frequently recognised causes of COVID-19 include a viral or bacterial factor, and - to a lesser degree - al-

\begin{tabular}{|c|c|}
\hline $\begin{array}{c}\text { COVID causes } \\
\text { Przyczyny COVID-19 }\end{array}$ & $M(S D)$ \\
\hline $\begin{array}{c}\text { Stress and worry } \\
\text { Stres izamartwianie się }\end{array}$ & $1.91(1.21)$ \\
\hline $\begin{array}{l}\text { Some personality traits } \\
\text { Niektóre cechy osobowości }\end{array}$ & $1.56(0.94)$ \\
\hline $\begin{array}{c}\text { Overstrain } \\
\text { Przepracowanie } \\
\end{array}$ & $2.19(1.30)$ \\
\hline $\begin{array}{l}\text { Negative mood } \\
\text { Negatywny nastrój }\end{array}$ & 1.99 (1.26) \\
\hline $\begin{array}{l}\text { Unhealthy diet } \\
\text { Niezdrowa dieta }\end{array}$ & $2.36(1.34)$ \\
\hline $\begin{array}{l}\text { Viruses or bacteria } \\
\text { Wirusy lub bakterie }\end{array}$ & $4.43(0.94)$ \\
\hline $\begin{array}{c}\text { Genetic factors } \\
\text { Czynniki genetyczne }\end{array}$ & $2.51(1.37)$ \\
\hline $\begin{array}{l}\text { Environmental pollution } \\
\text { Skażenieśrodowiska }\end{array}$ & $2.49(1.37)$ \\
\hline $\begin{array}{c}\text { Altered immunity } \\
\text { Zmieniona odporność }\end{array}$ & $3.76(1.31)$ \\
\hline $\begin{array}{l}\text { Smoking and/or illicit drugs } \\
\text { Palenie i/lub narkotyki }\end{array}$ & $2.64(1.41)$ \\
\hline $\begin{array}{l}\text { Alcohol } \\
\text { Alkohol }\end{array}$ & $2.28(1.42)$ \\
\hline $\begin{array}{l}\text { Coffee } \\
\text { Kawa } \\
\end{array}$ & $1.76(0.98)$ \\
\hline $\begin{array}{l}\text { Pre-existing medical conditions } \\
\text { Wcześniejsze obciqżenia medyczne }\end{array}$ & $3.29(1.51)$ \\
\hline $\begin{array}{c}\text { Older age } \\
\text { Starszy wiek } \\
\end{array}$ & $3.31(1.56)$ \\
\hline $\begin{array}{l}\text { Bad luck } \\
\text { Pech }\end{array}$ & $2.93(1.55)$ \\
\hline $\begin{array}{l}\text { Punishment for sins } \\
\text { Kara za grzechy }\end{array}$ & $1.31(0.78)$ \\
\hline
\end{tabular}

Tab. 4. Representation of causes of COVID-19 (means and standard deviations)

Tab. 4. Reprezentacja przyczyn COVID-19 (średnie i odchylenia standardowe)

\section{Reprezentacja COVID-19: Przebieg ostry/ chroniczny, Cykliczność przebiegu, Konsekwencje, Kontrola osobista, Kontrola leczenia, Koherencja choroby, Reprezentacja emocjonalna}

Ze względu na to, że podskale IPQ-R zawierają różne liczby itemów, wyniki surowe (tab. 3) zostały wyrażone na skali procentowej i w rezultacie możliwe było określenie profilu poznawczej i emocjonalnej reprezentacji COVID-19 (ryc. 1). Według wszystkich respondentów COVID-19 wywołuje w nich negatywne emocje (Reprezentacja emocjonalna) i jest spostrzegany jako choroba, która znacząco wpływa na ich życie osobiste (Konsekwencje). Choroba ma tendencję do bycia raczej długotrwałym problemem niż krótkotrwałym stanem (Przebieg ostry/chroniczny) oraz wiąże się z częstymi nawrotami i wycofywaniem się objawów (Cykliczność przebiegu). Respondenci wykazywali umiarkowane przekonanie, iż przebieg COVID-19 (poprawa lub pogorszenie) może być powiązany z zachowaniem chorego 


\begin{tabular}{|c|c|}
\hline $\begin{array}{c}\text { Risk mitigation } \\
\text { Czynniki zmniejszające ryzyko }\end{array}$ & $M(S D)$ \\
\hline $\begin{array}{l}\text { Washing hands } \\
\text { Mycie rqak }\end{array}$ & $4.59(0.85)$ \\
\hline $\begin{array}{l}\text { Wearing masks } \\
\text { Noszenie maseczek }\end{array}$ & $4.01(1.29)$ \\
\hline $\begin{array}{l}\text { Wearing face shields } \\
\text { Noszenie przyłbic }\end{array}$ & 3.44 (1.37) \\
\hline $\begin{array}{c}\text { Avoiding crowded places (weddings, shops, trains, etc.) } \\
\text { Unikanie zattoczonych miejsc (sklepów, pociagów, } \\
\text { sal weselnych etc.) }\end{array}$ & $4.38(1.06)$ \\
\hline $\begin{array}{c}\text { Healthy diet } \\
\text { Zdrowa dieta }\end{array}$ & 4.11 (1.11) \\
\hline $\begin{array}{l}\text { Exercise } \\
\text { Ćwiczenia }\end{array}$ & 4.04 (1.09) \\
\hline $\begin{array}{l}\text { Avoiding individuals who have contact with patients } \\
\text { (doctors, nurses) } \\
\text { Unikanie osób majacych kontakt z pacjentami } \\
\text { (lekarzy, opiekunów) }\end{array}$ & $3.85(1.095)$ \\
\hline $\begin{array}{l}\text { Avoiding individuals who have contact with many people } \\
\text { (teachers, hairdressers) } \\
\text { Unikanie osób majacych kontaktyz wieloma innymi osobami } \\
\text { (nauczycieli, fryzjerów) }\end{array}$ & $3.53(1.24)$ \\
\hline $\begin{array}{l}\text { Avoiding meetings with peers (at school, workplace) } \\
\text { Unikanie spotkań z rówieśnikami (w szkole, miejscu pracy) }\end{array}$ & $3.34(1.33)$ \\
\hline $\begin{array}{l}\text { Getting vaccinated against flu } \\
\text { Szczepienie się przeciwko grypie }\end{array}$ & $2.59(1.30)$ \\
\hline $\begin{array}{l}\text { Taking vitamins and other supplements } \\
\text { Zażywanie witamin i innych suplementów }\end{array}$ & $3.58(1.27)$ \\
\hline $\begin{array}{l}\text { Following media reports concerning the scale of the risk } \\
\text { Śledzenie doniesień medialnych dotyczących skali ryzyka }\end{array}$ & $2.52(1.44)$ \\
\hline $\begin{array}{l}\text { Refraining from traveling and social gatherings } \\
\text { Powstrzymanie się od podróżowania i spotkań towarzyskich }\end{array}$ & $3.74(1.26)$ \\
\hline $\begin{array}{l}\text { Avoiding sick people and places frequently attended } \\
\text { by patients (hospitals, clinics) } \\
\text { Unikanie osób chorych i miejsc często uczeszczanych } \\
\text { przez chorych (szpitali, przychodni) }\end{array}$ & 4.14 (1.13) \\
\hline $\begin{array}{l}\text { Keeping the recommended distance in all situations } \\
\text { Utrzymywanie rekomendowanego dystansu } \\
\text { we wszystkich sytuacjach }\end{array}$ & $3.93(1.26)$ \\
\hline $\begin{array}{l}\text { Fervent prayer } \\
\text { Żarliwa modlitwa }\end{array}$ & $1.83(1.24)$ \\
\hline
\end{tabular}

Tab. 5. Perception of factors mitigating the risk of COVID-19 (means and standard deviations)

Tab. 5. Percepcja czynników ograniczających ryzyko COVID-19 (średnie i odchylenia standardowe)

According to all the respondents, punishment for sins, excessive consumption of coffee, stress as well as emotional and personality traits are the least likely causes of the disease (Tab. 4).

Although punishment for sins, as a cause of COVID-19, was rated as the least likely option, men tended to associate these factors with the disease to a greater extent compared to women $(M=1.52, S D=1.09 ; M=1.24, S D=0.65, p=0.07)$. Compared to the other respondents, those who had had contact with people affected by COVID-19, were more likely to recognise overstrain $(M=2.39, S D=1.37 ; M=1.89, S D=1.13$, $p \leq 0.01)$ or unhealthy $\operatorname{diet}(M=2.54, S D=1.39 ; M=2.09$, $S D=1.22, p<0.05)$ as important causes of the disease. The belief that COVID-19 is caused by a virus was found to decrease
(Kontrola osobista). Nieco słabsze okazało się przekonanie, że leczenie może poprawiać sprawność chorych czy zapobiec negatywnym skutkom (Kontrola leczenia). COVID-19 był postrzegany jako choroba tajemnicza, niełatwa do zrozumienia (Koherencja choroby). Kobiety miały tendencję do raportowania silniejszych emocji negatywnych dotyczących COVID-19 niż mężczyźni $(M=23,96, S D=6,21 ; M=21,93, S D=7,09, p=0,05)$. Respondenci, którzy rozmawiali z opiekunami/lekarzami na temat COVID-19, byli bardziej skłonni niż pozostali do wskazywania przewlekłej natury choroby $(M=20,50$, $S D=4,44 ; M=18,61, S D=4,23, p<0,01)$ i poważnych konsekwencji $(M=23,29, S D=4,37 ; M=21,77, S D=4,79$, $p<0,01)$. Wraz z wiekiem badanych umacniało się przekonanie, że choroba może mieć poważne konsekwencje $(\rho=0,18, p<0,05)$. Osoby obciążone chorobami przewlekłymi (ChD) cechowały się odmiennymi przekonaniami niż osoby nieobciążone (nChD): uważały, że COVID-19 jest raczej długotrwałą chorobą $\left(M_{\mathrm{ChD}}=20,76, S D=3,77\right.$; $\left.M_{\mathrm{nChD}}=19,15, S D=4,55, p<0,05\right)$ niż krótkotrwałą sytuacją. Respondenci z wyższym poziomem wykształcenia uzyskiwali istotnie wyższe wyniki dotyczące negatywnych konsekwencji choroby $\left(M_{\mathrm{LL}}=21,30, S D=4,80\right.$; $\left.M_{\mathrm{HL}}=23,55, S D=4,26, p \leq 0,001\right)$ i byli bardziej skłonni postrzegać COVID-19 jako chorobę chroniczną, a nie o ostrym przebiegu $\left(M_{\mathrm{HL}}=14,90, S D=3,03 ; M_{\mathrm{LL}}=14,26\right.$, $S D=3,06, p=0,05)$.

\section{Reprezentacja przyczyn}

Najczęściej wskazywane przyczyny COVID-19 obejmują czynnik wirusowy lub bakteryjny i - w mniejszym stopniu zmienioną odporność, starszy wiek oraz istniejące wcześniej obciążenia chorobowe. Według wszystkich respondentów najmniej prawdopodobnymi przyczynami choroby są kara za grzechy, nadmierne spożycie kawy, stres czy cechy emocjonalno-osobowościowe (tab. 4).

Chociaż kara za grzechy została oceniona jako najmniej prawdopodobna przyczyna COVID-19, mężczyźni w większym stopniu niż kobiety mieli tendencję do wiązania tego czynnika z chorobą $(M=1,52, S D=1,09 ; M=1,24$, $S D=0,65, p=0,07)$. W porównaniu z pozostałymi badanymi ci, którzy mieli kontakt z osobami dotkniętymi COVID-19, byli bardziej skłonni wskazywać na przepracowanie $(M=2,39, S D=1,37 ; M=1,89, S D=1,13, p \leq 0,01)$ lub niezdrową dietę $(M=2,54, S D=1,39 ; M=2,09$, $S D=1,22, p<0,05)$ jako główną przyczynę choroby. Przekonanie, że COVID-19 jest wywoływany przez wirus, malało wraz z wiekiem $(\rho=-0,16, p<0,05)$. Respondenci z chorobami przewlekłymi (ChD) w porównaniu z osobami bez podobnych obciążeń (nChD) postrzegali palenie jako ważniejszy czynnik odpowiedzialny za chorobę $\left(M_{\mathrm{ChD}}=3,05, S D=1,49 ; M_{\mathrm{nChD}}=2,51, S D=2,51, p<0,05\right)$. Uczestnicy z niższym poziomem edukacji (LL) w większym stopniu uznawali (negatywne) cechy emocjonalności za jedną z przyczyn COVID-19 $\left(M_{\mathrm{LL}}=2,23, S D=1,39\right.$; 


\begin{tabular}{|c|c|c|c|c|c|c|c|}
\hline $\begin{array}{l}\text { IPQ-R subscales } \\
I P Q-R \text { - podskale }\end{array}$ & $\begin{array}{c}\text { Contact with } \\
\text { patients, } \boldsymbol{\beta} \\
\text { Kontakt } z \text { chorym, } \beta\end{array}$ & $\begin{array}{c}\text { Contact with caregiver/ } \\
\text { doctor, } \boldsymbol{\beta} \\
\text { Kontakt z opiekunami/ } \\
\text { lekarzem, } \beta\end{array}$ & $\begin{array}{c}\text { Education level, } \boldsymbol{\beta} \\
\text { Poziom wykształcenia, } \beta\end{array}$ & $\begin{array}{c}\text { Gender, } \boldsymbol{\beta} \\
\text { Pté, } \beta\end{array}$ & $\boldsymbol{F}$ & $p$ & $\begin{array}{c}R^{2} \text { adj. } \\
R^{2} \text { skorygowane }\end{array}$ \\
\hline $\begin{array}{l}\text { Timeline Acute/Chronic } \\
\text { Przebieg ostry/chroniczny }\end{array}$ & 0.073 & $\begin{array}{c}0.24 \\
\left(p=0.004^{* *}\right)\end{array}$ & 0.023 & $\begin{array}{c}0.13 \\
\left(p=0.05^{*}\right)\end{array}$ & $\begin{array}{c}3.233 \\
(4,177)\end{array}$ & $0.014^{*}$ & 0.05 \\
\hline $\begin{array}{c}\text { Timeline Cyclical } \\
\text { Cyklicznoś́ przebiegu }\end{array}$ & 0.082 & 0.05 & 0.105 & 0.027 & $\begin{array}{l}1.3767 \\
(4,185) \\
\end{array}$ & 0.244 & \\
\hline $\begin{array}{l}\text { Consequences } \\
\text { Konsekwencje }\end{array}$ & $\begin{array}{c}0.17 \\
\left(p=0.05^{*}\right)\end{array}$ & 0.08 & $\begin{array}{c}0.224 \\
\left(p=0.003^{* *}\right)\end{array}$ & 0.04 & $\begin{array}{c}4.43 \\
(4,182) \\
\end{array}$ & $0.001^{* * *}$ & 0.08 \\
\hline $\begin{array}{l}\text { Personal Control } \\
\text { Kontrola osobista }\end{array}$ & $\begin{array}{c}0.19 \\
\left(p=0.027^{*}\right)\end{array}$ & 0.02 & 0.06 & 0.08 & $\begin{array}{c}2.059 \\
(4,180)\end{array}$ & $0.08^{t}$ & 0.03 \\
\hline $\begin{array}{c}\text { Treatment Control } \\
\text { Kontrola leczenia }\end{array}$ & 0.036 & $\begin{array}{c}0.188 \\
\left(p=0.02^{*}\right)\end{array}$ & $\begin{array}{c}0.186 \\
\left(p=0.046^{*}\right)\end{array}$ & 0.08 & $\begin{array}{c}1.37 \\
(4,175) \\
\end{array}$ & $0.05^{*}$ & 0.03 \\
\hline $\begin{array}{l}\text { Illness Coherence } \\
\text { Koherencja choroby }\end{array}$ & 0.022 & 0.08 & $\begin{array}{c}0.12 \\
\left(p=0.06^{\dagger}\right)\end{array}$ & 0.13 & $\begin{array}{c}1.28 \\
(4,175)\end{array}$ & 0.28 & \\
\hline $\begin{array}{l}\text { Emotional Representations } \\
\text { Reprezentacja emocjonalna }\end{array}$ & 0.127 & 0.08 & 0.05 & 0.12 & $\begin{array}{c}1.58 \\
(4,180)\end{array}$ & 0.18 & \\
\hline
\end{tabular}

Tab. 6. Determinants of cognitive and emotional representation of COVID-19: categorical regression (CATREG)

Tab. 6. Determinanty poznawczej i emocjonalnej reprezentacji COVID-19: regresja kategorialna (CATREG)

with age $(\rho=-0.16, p<0.05)$. The respondents with chronic diseases $(\mathrm{ChD})$, compared to those with no such conditions (nChD), perceived smoking as a more important factor contributing to the disease $\left(M_{\mathrm{ChD}}=3.05, S D=1.49 ; M_{\mathrm{nChD}}=2.51\right.$, $S D=2.51, p<0.05)$. The participants with lower level of education (LL) to a greater degree recognised (negative) emotional traits as one of the causes of COVID-19 $\left(M_{\mathrm{LL}}=2.23\right.$, $\left.S D=1.39 ; M_{\mathrm{HL}}=1.76, S D=1.09, p<0.05\right)$, were less likely to point to the virus as an important cause of the disease $\left(M_{\mathrm{LL}}=4.22, S D=1.06 ; M_{\mathrm{HL}}=4.63, S D=0.76, p \leq 0.001\right)$, and associated COVID-19 with diet to a greater extent $\left(M_{\mathrm{LL}}=2.58\right.$, $\left.S D=1.39 ; M_{\mathrm{HL}}=2.16, S D=1.27, p<0.05\right)$.

\section{Behaviours reducing the risk of illness}

According to all subjects, such behaviours as washing hands, avoiding crowded places, keeping a healthy diet and participation in sports to minimise the risk of contracting COVID-19 the largest degree. Getting vaccinated against flu, following media reports and fervent prayer were rated as the least recommended preventive measures. Wearing masks was seen as more effective than wearing shields (Tab. 5).

Men were more likely to recognise prayer as a factor minimising the risk compared to women $(M=2.15, S D=1.56 ; M=1.72$, $S D=1.10, p<0.05)$. The importance of washing hands as a preventive measure was less frequently acknowledged by men than by women $(M=4.45, S D=0.90 ; M=4.64, S D=0.83, p=0.05)$. The respondents who had talked with caregivers/doctors about COVID-19, compared to the others, more frequently emphasised the protective role of facial masks $(M=4.19, S D=1.41$; $M=3.86, S D=1.40, p=0.06)$ and the importance of keeping distance $(M=4.10, S D=1.03 ; M=3.78, S D=1.43, p=0.06)$. With age, there was an increasing belief that exercise (physical) can minimise the risk of infection $(\rho=0.17, p<0.05)$, and
$\left.M_{\mathrm{HL}}=1,76, S D=1,09, p<0,05\right)$, rzadziej wskazywali na wirus jako istotną przyczynę choroby $\left(M_{\mathrm{LL}}=4,22, S D=1,06\right.$; $\left.M_{\mathrm{HL}}=4,63, S D=0,76, p \leq 0,001\right)$ i w większym stopniu wiązali COVID-19 z dietą $\left(M_{\mathrm{LL}}=2,58, S D=1,39 ; M_{\mathrm{HL}}=2,16\right.$, $S D=1,27, p<0,05)$.

\section{Zachowania redukujące ryzyko choroby}

Według badanych mycie rąk, unikanie zatłoczonych miejsc, zdrowa dieta i uprawianie sportu w największym stopniu minimalizują ryzyko zachorowania na COVID-19. Szczepienia przeciwko grypie, śledzenie doniesień medialnych i żarliwa modlitwa zostały określone jako najmniej skuteczne metody prewencji. Noszenie maseczek badani uznali za bardziej efektywne od noszenia przyłbic (tab. 5).

Mężczyźni w porównaniu z kobietami traktowali modlitwę jako bardziej prawdopodobny czynnik ochronny $(M=2,15$, $S D=1,56 ; M=1,72, S D=1,10, p<0,05)$. Konieczność mycia rąk jako metoda prewencji była rzadziej wspominana przez mężczyzn niż przez kobiety $(M=4,45, S D=0,90 ; M=4,64$, $S D=0,83, p=0,05)$. Respondenci, którzy rozmawiali z opiekunami/lekarzami na temat COVID-19, częściej niż inni podkreślali ochronną rolę maseczek $(M=4,19, S D=1,41$; $M=3,86, S D=1,40, p=0,06)$ i konieczność utrzymywania dystansu $(M=4,10, S D=1,03 ; M=3,78, S D=1,43$, $p=0,06)$. Wraz z wiekiem narastało przekonanie, że ćwiczenia fizyczne mogą minimalizować ryzyko infekcji ( $\rho=0,17$, $p<0,05)$, i słabło przekonanie, że ryzyko to można redukować przez unikanie kontaktu z osobami mającymi styczność $z$ chorymi $(\rho=-0,18, p<0,05)$ lub kontaktu z osobami, które w związku ze swoją pracą spotykają na co dzień wielu ludzi $(\rho=-0,17, p<0,05)$. Respondenci z niższym poziomem edukacji przywiązywali mniejszą wagę do mycia rąk $\left(M_{\mathrm{LL}}=4,44, S D=1,02 ; M_{\mathrm{HL}}=4,74, S D=0,63, p<0,05\right)$, diety $\left(M_{\mathrm{LL}}=3,90, S D=1,24 ; M_{\mathrm{HL}}=4,31, S D=0,93, p<0,05\right)$, 
people who had contact with ill persons $(\rho=-0.18, p<0.05)$ or those who had contact with many people in connection to their job $(\rho=-0.17, p<0.05)$. As regards the ways to mitigate the risk of infection, respondents with lower education attributed less importance to washing hands $\left(M_{\mathrm{LL}}=4.44, S D=1.02\right.$; $\left.M_{\mathrm{HL}}=4.74, S D=0.63, p<0.05\right), \operatorname{diet}\left(M_{\mathrm{LL}}=3.90, S D=1.24\right.$; $\left.M_{\mathrm{HL}}=4.31, S D=0.93, p<0.05\right)$, avoiding crowded places $\left(M_{\mathrm{LL}}=4.25, S D=1.01 ; M_{\mathrm{HL}}=4.50, S D=1.01, p=0.05\right)$, exercise $\left(M_{\mathrm{LL}}=3.80, S D=1.18 ; M_{\mathrm{HL}}=4.26, S D=0.95, p<0.01\right)$, getting vaccinated against flu $\left(M_{\mathrm{LL}}=2.41, S D=1.11, M_{\mathrm{HL}}=2.77\right.$, $S D=1.43, p=0.06)$, and keeping social distance $\left(M_{\mathrm{LL}}=3.72\right.$, $\left.S D=1.35 ; M_{\mathrm{HL}}=4.13, S D=1.14, p<0.05\right)$.

\section{Major determinants of cognitive and emotional representation of COVID-19}

Categorical regression (CATREG) was computed to assess the impact of interactions between the variables on opinions concerning COVID-19 (Tab. 6). The determinants applied included: gender $(\mathrm{m} / \mathrm{f})$, education level (higher/lower), contact with an ill person (yes/no) and contact with a caregiver/doctor (yes/no), while results obtained in the IPQ-R subscales were used as dependent variables.

Although these variables explain the variance in IPQ-R results to a small degree, certain regularities should be highlighted. The opinions concerning COVID-19 duration are affected by the interactions of two variables, i.e. gender and contact with a caregiver/doctor: the respondents who had had such contacts believed the disease was more long-lasting $(M=20.50$, $S D=4.44)$ compared to those who reported no such contact $(M=18.61, S D=4.23)$, while women rated COVID-19 as a more chronic condition $(M=19.3, S D=4.41)$ compared to men $(M=18.6, S D=4.37)$. As regards disease consequences, the respondents with higher education perceived more negative consequences of COVID-19 $(M=23.55, S D=4.26)$ than those with lower education $(M=21.30, S D=4.80)$, however those respondents who had had no contact with ill persons slightly more negatively assessed the consequences of COVID-19 $(M=22.64, S D=4.60)$ than those who had experienced such contact $(M=22.34, S D=4.71)$. A higher sense of personal control over the disease was expressed by the respondents who had had no contact with any patients affected by COVID-19 $(M=19.00, S D=5.01)$, compared to those who had experienced such contact $(M=18.6, S D=4.8)$. The respondents who had talked about the disease with a doctor/caregiver $(M=13.49, S D=3.53)$ presented a slightly higher sense of treatment control than other respondents $(M=13.43$, $S D=3.97$ ); additionally, individuals with higher education were more likely to believe that treatment may positively affect the course of the disease $(M=13.85, S D=3.97)$, as compared to respondents with lower education $(M=12.35, S D=3.05)$.

\section{DISCUSSION}

COVID-19 representation affects people's health-oriented behaviours, which is particularly important if vaccination is unikania zatłoczonych miejsc $\left(M_{\mathrm{LL}}=4,25, S D=1,01\right.$; $\left.M_{\mathrm{HL}}=4,50, S D=1,01, p=0,05\right)$, ćwiczeń $\left(M_{\mathrm{LL}}=3,80\right.$, $\left.S D=1,18 ; M_{\mathrm{HL}}=4,26, S D=0,95, p<0,01\right)$, szczepień przeciwko grypie $\left(M_{\mathrm{LL}}=2,41, S D=1,11, M_{\mathrm{HL}}=2,77, S D=1,43\right.$, $p=0,06)$ i utrzymywania dystansu społecznego $\left(M_{\mathrm{LL}}=3,72\right.$, $\left.S D=1,35 ; M_{\mathrm{HL}}=4,13, S D=1,14, p<0,05\right)$.

\section{Główne determinanty poznawczej i emocjonalnej reprezentacji COVID-19}

Aby ocenić wpływ interakcji różnych czynników na poznawczo-emocjonalną reprezentację COVID-19, zastosowano regresję kategorialną (CATREG) (tab. 6). Za determinanty uznano płeć (mężczyzna/kobieta), poziom edukacji (wyższy/niższy), kontakt z osobą chorą na COVID-19 (tak/nie) i kontakt $\mathrm{z}$ opiekunem/lekarzem (tak/nie). Wyniki w podskalach IPQ-R uznano za zmienne zależne.

Chociaż wymienione czynniki w małym stopniu wyjaśniały wariancję wyników w IPQ-R, warto podkreślić pewne prawidłowości. Przekonania o przebiegu COVID-19 są kształtowane przez interakcję dwóch zmiennych: płci i kontaktu z opiekunem/lekarzem. Respondenci, którzy taki kontakt mieli, częściej sądzili, że choroba jest długotrwała $(M=20,50, S D=4,44)$, niż ci, którzy raportowali brak kontaktu $(M=18,61, S D=4,23)$. Kobiety oceniały COVID-19 jako chorobę bardziej chroniczną $(M=19,3, S D=4,41)$ w porównaniu z mężczyznami $(M=18,6, S D=4,37)$. Respondenci z wyższym poziomem edukacji spostrzegali więcej negatywnych konsekwencji COVID-19 ( $M=23,55$, $S D=4,26)$ niż ci z niższym poziomem wykształcenia $(M=21,30, S D=4,80)$. Ankietowani, którzy nie mieli kontaktu z chorymi, nieco bardziej negatywnie oceniali konsekwencje COVID-19 $(M=22,64, S D=4,60)$ niż ci, którzy doświadczyli takiego kontaktu $(M=22,34, S D=4,71)$. Uczestnicy, którzy nie mieli kontaktu z pacjentami z COVID-19, prezentowali silniejsze poczucie kontroli nad chorobą $(M=19,00, S D=5,01)$ niż ci, którzy kontaktowali się z chorymi $(M=18,6, S D=4,8)$. Respondenci, którzy rozmawiali o chorobie z lekarzem/opiekunami, mieli nieco silniejsze poczucie kontroli leczenia $(M=13,49, S D=3,53)$ niż pozostali uczestnicy $(M=13,43, S D=3,97)$. Dodatkowo osoby z wyższym wykształceniem były bardziej skłonne sądzić, że leczenie może pozytywnie wpływać na przebieg choroby $(M=13,85, S D=3,97)$, niż respondenci o niższym poziomie wykształcenia $(M=12,35, S D=3,05)$.

\section{OMÓWIENIE}

Reprezentacja COVID-19 wyznacza zachowania związane ze zdrowiem, które są niezwykle istotne, jeśli uczestnictwo w szczepieniach jest dobrowolne, a pewne restrykcje muszą zostać utrzymane. Niektóre z naszych ustaleń są ważne, jeśli wziąć pod uwagę obecną sytuację w Unii Europejskiej (kolejna fala pandemii, kontynuacja programów szczepień), inne dane uzyskane w badaniu dają nadzieję na wdrożenie zachowań prozdrowotnych. 
voluntary and current restrictions must be maintained. Some of our findings are important if we take into account the present situation in the European Union (next wave of the pandemic, continuation of immunisation programmes); other data identified in this study give hope that health-oriented behaviours may be implemented. As regards the former, most notably the belief that COVID-19 indeed exists was expressed by only three in four respondents, and according to many participants the effects of the disease are overestimated in media reports, while its course may be similar to that of influenza. The lack of knowledge related to neurological and neuropsychological complications suggests that this aspect of the disease was insufficiently emphasised in the mass media before the second wave of the pandemic. Evidence presented by other researchers (LugoGonzález et al., 2020) showed that respondents - 1,560 adolescents and adults from various Mexican states - were aware of only some symptoms of COVID-19. It would be worthwhile to more effectively promote the knowledge of the possible mechanisms and symptoms of the disease (Guadarrama-Ortiz et al., 2020). Our findings, showing a relationship between the education level and knowledge of disease causes, clinical picture and ways to mitigate the risks, are consistent with those reported by Salimi et al. (2020). Lower education level was associated with poorer access to up-to-date information about the pandemic (Charoenwong et al., 2020), and with a greater likelihood of infecting other people, including whole families (Liu et al., 2020). Conversely, Nivette et al. (2021) found that individuals with higher education more frequently failed to comply with restrictions in the situation of the pandemic. On the other hand, higher education level corresponded to greater willingness to get a COVID-19 vaccine (Guidry et al., 2021). With age, the respondents are less likely to agree that COVID-19 is caused by a virus and it is necessary to comply with public health measures. Similar findings were reported by Pasion et al. (2020). The current evidence suggests that young adults are more hesitant about the need to get a vaccine (Murphy et al., 2021), while older age corresponds to more positive attitudes with respect to vaccination (Sherman et al., 2021), despite poor knowledge about the disease (Szczerbińska et al., 2014).

The factors which may favourably affect health-oriented behaviours include the widespread awareness that COVID-19 is caused by a virus, and the risk of illness is linked to altered immunity, older age, and pre-existing conditions. The cognitive representation of COVID-19 is positively affected by higher education level, and knowledge about the illness acquired through contacts with ill individuals or medical personnel/caregivers. The respondents who had reported such experiences attributed a greater importance to certain preventive behaviours and noticed the negative consequences of the disease. Women tended to have a better knowledge of the factors minimising the risks.

The cognitive and emotional representation of COVID-19 comprises negative emotions, a belief that the disease significantly affects one's personal life and career, and an opinion that the condition is long-lasting and associated with fre-
Przekonanie, że COVID-19 rzeczywiście istnieje, wyraziło zaledwie trzech na czterech respondentów. Według wielu uczestników skutki choroby są przeceniane w doniesieniach medialnych i może ona mieć przebieg podobny do grypy. Brak wiedzy o powikłaniach neurologicznych i neuropsychologicznych sugeruje, że ten aspekt choroby nie był dostatecznie podkreślany w mediach przed drugą falą pandemii. Dane z innych badań (Lugo-González et al., 2020) potwierdziły, że respondenci - 1560 adolescentów i dorosłych z różnych stanów Meksyku - znali jedynie niektóre symptomy COVID-19. Warto byłoby skuteczniej promować wiedzę o możliwych mechanizmach i objawach choroby (Guadarrama-Ortiz et al., 2020). Nasze ustalenia pokazujące związek między poziomem wykształcenia a wiedzą o przyczynach, obrazie klinicznym i sposobach ograniczania ryzyka są zgodne z opisanymi przez Salimiego i wsp. (2020). Niższy poziom wykształcenia był związany z gorszym dostępem do aktualnych informacji o pandemii (Charoenwong et al., 2020) i większym prawdopodobieństwem zakażania innych osób, również całych rodzin (Liu et al., 2020). Nivette i wsp. (2021) stwierdzili, że osoby z wyższym wykształceniem częściej nie przestrzegały ograniczeń pandemicznych. Zarazem jednak wyższy poziom wykształcenia odpowiadał większej chęci otrzymania szczepionki przeciw COVID-19 (Guidry et al., 2021). Wraz z wiekiem respondenci coraz rzadziej zgadzają się ze stwierdzeniem, że COVID-19 jest wywoływany przez wirus i że należy przestrzegać zasad zdrowia publicznego. Podobne wyniki przedstawili Pasion i wsp. (2020). Obecne dowody sugerują, że młodzi dorośli są bardziej niezdecydowani co do konieczności zaszczepienia się (Murphy et al., 2021), podczas gdy starszy wiek odpowiada bardziej pozytywnym postawom w zakresie szczepień (Sherman et al., 2021) - pomimo niewielkiej wiedzy o chorobie (Szczerbińska et al., 2014).

Do czynników, które mogą korzystnie wpływać na zachowania prozdrowotne, należy świadomość, że COVID-19 jest wywoływany przez wirus, a ryzyko choroby wiąże się ze zmienioną odpornością, starszym wiekiem i wcześniejszymi schorzeniami. Na poznawczą reprezentację COVID-19 pozytywnie wpływają wykształcenie wyższe i wiedza o chorobie nabyta poprzez kontakt z osobami chorymi lub personelem medycznym/opiekunami. Respondenci, którzy zgłosili takie doświadczenie, przypisują większą wagę określonym zachowaniom profilaktycznym i zauważają negatywne konsekwencje choroby. Kobiety mają zwykle lepszą wiedzę na temat czynników minimalizujących ryzyko.

Poznawczo-emocjonalna reprezentacja COVID-19 obejmuje negatywne emocje i przekonanie, że choroba ma istotny wpływ na życie osobiste i karierę zawodową oraz że jest to stan długotrwały, związany z częstymi zaostrzeniami, a następnie ustępowaniem objawów. Możliwości kontrolowania choroby poprzez własne zachowanie oraz kontrolowania stanu zdrowia lub zapobiegania negatywnym skutkom choroby poprzez leczenie oceniono 
The ability to control the illness by one's own behaviour and to control one's health status, or to prevent negative effects of the disease through treatment, was assessed as average. Evidence of negative emotions induced by COVID-19 was reported in many studies (Wang et al., 2020; Zhang et al., 2020). Our findings seem to be consistent with other evidence showing that women report a greater sense of negative emotions related to COVID-19 (Wang et al., 2020; Zhang et al., 2020). A moderate sense of personal control and treatment control in relation to COVID-19 may contribute to more negative emotions, a stronger tendency to ignore relevant recommendations, and unwillingness to get vaccinated (Murphy et al., 2021), particularly if COVID-19 is perceived as a disease similar to influenza and the risks are believed to be overestimated. A sense of illness coherence may be associated with one's own direct or indirect experience of the disease (Bellizzi and Blank, 2006; Sheikh, 2004). Factors of considerable importance in this case include personal resources, degree of social and emotional maturity, and subjectively estimated availability of support from friends or relatives and the healthcare system (Rommer et al., 2017; Shechter et al., 2020).

The survey discussed here was carried out towards the end of 2020. The dynamics of the pandemic and new evidence related to COVID-19 may have modified the content of its representation to a certain degree, nevertheless the data related to 7,032 participants from 16 European countries showed a relative temporal stability of COVID-19 perception (Dias Neto et al., 2021). This finding should be taken into account by those planning new steps in fighting the pandemic.

\section{CONCLUSIONS}

Beliefs related to COVID-19 are directly reflected in one's daily-life choices and actions, including healthy or unhealthy behaviours, as well as the willingness to get vaccinated. The authors showed that individual variables and experience of COVID-19 affected one's cognitive and emotional representation of the disease and one's beliefs concerning the mitigation of risks, and that these beliefs may have contributed to the development of the next waves of the pandemic. This means that information related to COVID-19 must be conveyed in a way adjusted to gender and age (Back et al., 2020) as well as education (van Deursen, 2020). Limitations of the present conclusions result from the fact that the study was carried out during a relatively short period of one week, at the time of the highest incidence of the disease in Poland since the outbreak of the pandemic. The group of respondents was not very large, and it is possible that the information related to the actual health status (COVID-19 infection) is not absolutely reliable due to the online method applied. Hence, the findings reflect the specific context connected with the state of the epidemic in Poland in November-December 2020.

\section{Conflict of interest}

The authors do not report any financial or personal affiliations to persons or organisations that could negatively affect the content of or claim to have rights to this publication. jako przeciętne. W wielu badaniach (Wang et al., 2020; Zhang et al., 2020) wykazano obecność negatywnych emocji wywoływanych przez COVID-19. Nasze ustalenia wydają się spójne z innymi dowodami, zgodnie z którymi kobiety zgłaszają więcej negatywnych emocji w związku z COVID-19 (Wang et al., 2020; Zhang et al., 2020). Umiarkowane poczucie osobistej kontroli i kontroli leczenia w odniesieniu do COVID-19 może się przyczyniać do większego nasilenia negatywnych emocji, silniejszej tendencji do ignorowania zaleceń i niechęci do szczepień (Murphy et al., 2021), szczególnie jeśli postrzega się COVID-19 jako chorobę podobną do grypy i uważa się, że ryzyko jest przeszacowane. Poczucie koherencji choroby może być związane $\mathrm{z}$ własnym bezpośrednim lub pośrednim doświadczeniem COVID-19 (Bellizzi i Blank, 2006; Sheikh, 2004). Czynnikami o dużym znaczeniu są tu zasoby osobiste, stopień dojrzałości społecznej i emocjonalnej oraz subiektywnie oszacowana dostępność wsparcia ze strony przyjaciół lub krewnych i systemu opieki zdrowotnej (Rommer et al., 2017; Shechter et al., 2020).

Prezentowane badania zostały przeprowadzone pod koniec 2020 roku. Dynamika pandemii i nowe dane na temat COVID-19 mogły w pewnym stopniu zmodyfikować zawartość reprezentacji choroby, niemniej dane 7032 badanych z 16 krajów Europy świadczą o względnej stabilności obrazu COVID-19 w czasie (Dias Neto et al., 2021). Warto o tym pamiętać, planując kolejne kroki w walce $\mathrm{z}$ pandemią.

\section{KONKLUZJE}

Przekonania związane z COVID-19 znajdują odzwierciedlenie w codziennych wyborach i działaniach - dotyczy to zdrowych lub niezdrowych zachowań, a także chęci zaszczepienia się. Autorki wykazały, że indywidualne zmienne i doświadczenie COVID-19 wpływają na poznawczo-emocjonalną reprezentację choroby i przekonania dotyczące redukcji ryzyka oraz że przekonania te mogły się przyczynić do rozwoju kolejnych fal pandemii. Oznacza to, że informacje na temat COVID-19 muszą być przekazywane w sposób dostosowany do płci i wieku (Back et al., 2020) oraz wykształcenia (van Deursen, 2020) odbiorców. Ograniczenia niniejszych wniosków wynikają $\mathrm{z}$ faktu, iż badanie zostało przeprowadzone w stosunkowo krótkim czasie (1 tydzień), w okresie gdy w Polsce notowano największą zachorowalność na COVID-19 od wybuchu pandemii. Grupa respondentów była niezbyt duża, a forma online mogła nie zapewniać wiarygodnych danych na temat stanu zdrowia uczestników (zakażenia COVID-19). Stąd wyniki badań odzwierciedlają specyficzny kontekst, związany ze stanem epidemii w Polsce w listopadzie-grudniu 2020 roku.

\section{Konflikt interesów}

Autorki nie zgłaszają żadnych finansowych ani osobistych powiązań z innymi osobami lub organizacjami, które mogtyby negatywnie wplynać na treść publikacji oraz rościć sobie prawo do tej publikacji. 


\section{References / Piśmiennictwo}

Ambroch M (ed.): Polska w liczbach 2020. Główny Urząd Statystyczny, Warszawa 2020.

Back A, Tulsky JA, Arnold RM: Communication skills in the age of COVID-19. Ann Intern Med 2020; 172: 759-760.

BCMM: Przekonania Polaków na temat źródła pochodzenia koronawirusa SARS-CoV-2. Katowice 2020. Available from: https://www. bcmm.com.pl/wp-content/uploads/2020/05/raport-BCMM$\%$ C5\%BAr\%C3\%B3d\%C5\%82o-koronawirusa-kwiecie\%C5\%84-2020.pdf.

Bellizzi KM, Blank TO: Predicting posttraumatic growth in breast cancer survivors. Health Psychol 2006; 25: 47-56.

Bishop GD: Understanding the understanding of illness: lay disease representations. In: Skelton JA, Croyle RT (eds.): Mental Representation in Health and Illness. Contributions to Psychology and Medicine. Springer, New York 1991: 32-59.

Boguszewski R, Makowska M, Bożewicz M et al.: The COVID-19 pandemic's impact on religiosity in Poland. Religions 2020; 11: 646.

Charoenwong B, Kwan A, Pursiainen V: Social connections with COVID-19-affected areas increase compliance with mobility restrictions. Sci Adv 2020; 6: eabc3054.

Cirrincione L, Plescia F, Ledda C et al.: COVID-19 pandemic: prevention and protection measures to be adopted at the workplace. Sustainability 2020; 12: 3603.

van Deursen AJ: Digital inequality during a pandemic: quantitative study of differences in COVID-19-related internet uses and outcomes among the general population. J Med Internet Res 2020; 22: e20073.

Dias Neto D, Nunes da Silva A, Roberto MS et al.: Illness perceptions of COVID-19 in Europe: predictors, impacts and temporal evolution. Front Psychol 2021; 12: 640955.

Gerhold L: COVID-19: risk perception and coping strategies. Results from a survey in Germany. PsyArXiv 2020, https://doi.org/ 10.31234/osf.io/xmpk4.

Górnicka M, Drywień ME, Zielinska MA et al.: Dietary and lifestyle changes during COVID-19 and the subsequent lockdowns among Polish adults: a cross-sectional online survey PLifeCOVID-19 study. Nutrients 2020; 12: 2324.

Guadarrama-Ortiz P, Choreño-Parra JA, Sánchez-Martínez CM et al.: Neurological aspects of SARS-CoV-2 infection: mechanisms and manifestations. Front Neurol 2020; 11: 1039.

Guidry JPD, Laestadius LI, Vraga EK et al.: Willingness to get the COVID-19 vaccine with and without emergency use authorization. Am J Infect Control 2021; 49: 137-142.

Kancelaria Prezesa Rady Ministrów: Premier: Podjęliśmy decyzję o zamknięciu wszystkich placówek oświatowych i szkół wyższych. 2020. Available from: https://www.gov.pl/web/premier/premierpodjelismy-decyzje-o-zamknieciu-wszystkich-placowek-oswiatowych-i-szkol-wyzszych.

Leventhal H, Leventhal EA, Contrada RJ: Self-regulation, health, and behavior: a perceptual-cognitive approach. Psychol Health 1998; 13: 717-733.

Litwin A, Masiak J: Mental disorders in people infected with the coronavirus SARS-CoV-2 - literature review. Polish Journal of Public Health 2019; 129: 141-144.

Liu H, Li X, Chen Q et al.: Illness perception, mood state and diseaserelated knowledge level of COVID-19 family clusters, Hunan, China. Brain Behav Immun 2020; 88: 30-31.

Lugo-González IV, Fernández-Vega M, Reynoso-Erazo L et al.: COVID-19 perception and preventive behaviors: a descriptive, comparative study by severity and perceived risk. Salud Mental 2020; 43: 285-292.

Mayo Clinic: Coronavirus disease 2019 (COVID-19). Symptoms and causes. Available from: https://www.mayoclinic.org/diseases-conditions/coronavirus/symptoms-causes/syc-20479963.
Ministerstwo Zdrowia: Pierwszy przypadek koronawirusa w Polsce. 2020. Available from: https://www.gov.pl/web/zdrowie/pierwszyprzypadek-koronawirusa-w-polsce.

Moss-Morris R, Weinman J, Petrie KJ et al.: The revised Illness Perception Questionnaire (IPQ-R). Psychol Health 2002; 17: 1-16.

Murphy J, Vallières F, Bentall RP et al.: Psychological characteristics associated with COVID-19 vaccine hesitancy and resistance in Ireland and the United Kingdom. Nat Commun 2021; 12: 29.

Nivette A, Ribeaud D, Murray A et al.: Non-compliance with COVID19-related public health measures among young adults in Switzerland: insights from a longitudinal cohort study. Soc Sci Med 2021; 268: 113370 .

Pacheco-Barrios K, Cardenas-Rojas A, Giannoni-Luza S et al.: COVID-19 pandemic and Farr's law: a global comparison and prediction of outbreak acceleration and deceleration rates. PLoS One 2020; 15: e0239175.

Pasion R, Paiva TO, Fernandes C et al.: The AGE effect on protective behaviors during the COVID-19 outbreak: sociodemographic, perceptions and psychological accounts. Front Psychol 2020; 11: 561785.

Pasternak A, Poraj-Weder M, Schier K: Polish adaptation and validation of the Revised Illness Perception Questionnaire (IPQ-R) in cancer patients. Front Psychol 2021; 12: 612609.

Rommer PS, Sühnel A, König N et al.: Coping with multiple sclerosis the role of social support. Acta Neurol Scand 2017; 136: 11-16.

Rozporządzenie Ministra Zdrowia z dnia 20 marca 2020 r. w sprawie ogłoszenia na obszarze Rzeczypospolitej Polskiej stanu epidemii. 2020. Available from: http://isap.sejm.gov.pl/isap.nsf/DocDetails. xsp?id=WDU20200000491.

Salimi A, ElHawary H, Diab N et al.: The North American layman's understanding of COVID-19: are we doing enough? Front Public Health 2020; 8: 358.

Shechter A, Diaz F, Moise N et al.: Psychological distress, coping behaviors, and preferences for support among New York healthcare workers during the COVID-19 pandemic. Gen Hosp Psychiatry 2020; 66: 1-8.

Sheikh AI: Posttraumatic growth in the context of heart disease. J Clin Psychol Med Settings 2004; 11: 265-273.

Sherman SM, Smith LE, Sim J et al.: COVID-19 vaccination intention in the UK: results from the COVID-19 vaccination acceptability study (CoVAccS), a nationally representative cross-sectional survey. Hum Vaccin Immunother 2021; 17: 1612-1621.

Skapinakis P, Bellos S, Oikonomou A et al.: Depression and its relationship with coping strategies and illness perceptions during the COVID-19 lockdown in Greece: a cross-sectional survey of the population. Depress Res Treat 2020; 2020: 3158954.

Szczerbińska K, Barańska I, Brzyski P et al.: Wiedza, przekonania i zachowania osób starszych wobec szczepień ochronnych zalecanych w starszym wieku. Gerontol Pol 2014; 2: 51-61.

Uniwersytet Warszawski: Raporty z badań ekspertów. Available from: https://covid.psych.uw.edu.pl/raporty.

Wang C, Pan R, Wan X et al.: Immediate psychological responses and associated factors during the initial stage of the 2019 coronavirus disease (COVID-19) epidemic among the general population in China. Int J Environ Res Public Health 2020; 17: 1729.

World Health Organization: Coronavirus disease (COVID-19). Symptoms. Available from: https://www.who.int/health-topics/ coronavirus\#tab=tab_3.

Yıldırım M, Güler A: Factor analysis of the COVID-19 Perceived Risk Scale: a preliminary study. Death Stud 2020: 1-8.

Zhang SX, Wang Y, Rauch A et al.: Unprecedented disruption of lives and work: health, distress and life satisfaction of working adults in China one month into the COVID-19 outbreak. Psychiatry Res 2020; 288: 112958 . 